\title{
RECEIVED
}

JUN 2.9995

OSTI

\section{Radiological Survey Results at 914 Black Oak Ridge Road, Wayne, New Jersey (WJ005)}

R. E. Rodriguez

C. A. Johnson 
This report has been reproduced directly from the best available copy.

Available to DOE and DOE contractors from the Office of Scientific and Technical Information, P.O. Box 62, Oak Ridge, TN 37831; prices available from (615) 576-8401, FTS 626-8401.

Available to the public from the National Technical Information Service, U.S. Department of Commerce, 5285 Port Royal Rd., Springfield, VA 22161.

This report was prepared as an account of work sponsored by an agency of the United States Government. Neither the United States Government nor any agency thereot, nor any of their employees, makes any warranty, express or implied, or assumes any legal liability or responsibility for the accuracy, completeness, or usefulness of any information, apparatus, product, or process disclosed, or represents that its use would not infringe privately owned rights. Reference herein to any specific commercial product, process, or service by trade name, trademark, manufacturer, or otherwise, does not necessarily constitute or imply its endorsement, recommendation, or favoring by the United States Government or any agency thereof. The views and opinions of authors expressed herein do not necessarily state or reflect those of the United States Government or any agency thereof. 


\section{DISCLAIMER}

Portions of this document may be illegible in electronic image products. Images are produced from the best available original document. 
HEALTH SCIENCES RESEARCH DIVISION

Environmental Restoration and Waste Management Non-Defense Programs

(Activity No. EX 2020010 ; ADS317AEX))

\section{Radiological Survey Results at 914 Black Oak Ridge Road, Wayne, New Jersey (WJ005)}

R. E. Rodriguez and C. A. Johnson

Date issued - May 1995

Investigation Team

R. D. Foley - Measurement Applications and Development Manager

R. E. Rodriguez- Survey Team Leader

Survey Team Members

R. E. Rodriguez

D. E. Rice

V. P. Patania

P. F. Tiner

A. C. Butler*

W. H. Shinpaugh*

*Midwest Technical, Inc.

Work performed by the Measurement Applications and Development Group

Prepared by the

OAK RIDGE NATIONAL LABORATORY

Oak Ridge, Tennessee 37831-6285

managed by

LOCKHEED MARTIN ENERGY SYSTEMS, INC.

for the

U. S. DEPARTMENT OF ENERGY

under contract DE-AC05-84OR21400 



\section{CONTENTS}

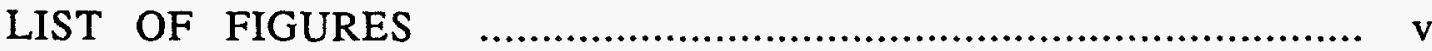

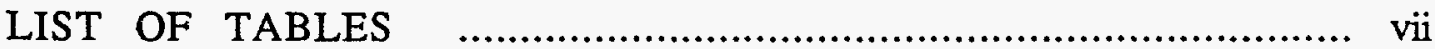

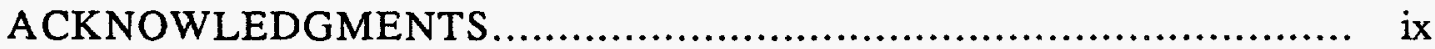

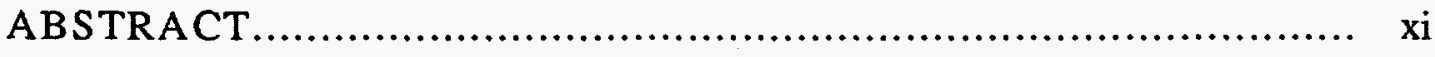

INTRODUCTION..................................................... 1

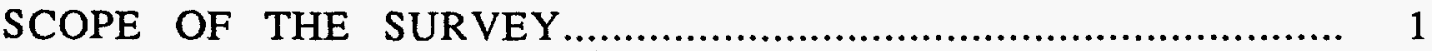

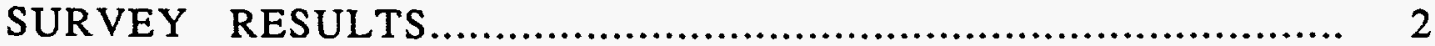

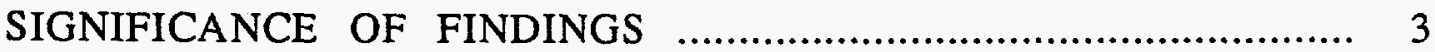

\section{DISCLAIMER}

This report was prepared as an account of work sponsored by an agency of the United States Government. Neither the United States Government nor any agency thereof, nor any of their employees, makes any warranty, express or implied, or assumes any legal liability or responsibility for the accuracy, completeness, or usefulness of any information, apparatus, product, or process disclosed, or represents that its use would not infringe privately owned rights. Reference herein to any specific commercial product, process, or service by trade name, trademark, manufacturer, or otherwise does not necessarily constitute or imply its endorsement, recommendation, or favoring by the United States Government or any agency thereof. The views and opinions of authors expressed herein do not necessarily state or reflect those of the United States Government or any agency thereof. 



\section{LIST OF FIGURES}

1 Diagram showing general location of the Wayne Interim Storage Site (WISS) relative to the Wayne and Pequannock, New Jersey

vicinity properties.

2 Diagram of the property at 914 Black Oak Ridge Rd., Wayne , New Jersey showing soil sampling locations and gamma measurements. 


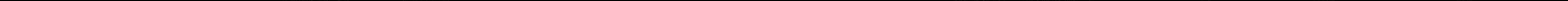




\section{LIST OF TABLES}

1 Concentrations of radionuclides in soil and other materials at 914 Black Oak Ridge Rd., Wayne, New Jersey (WJ005). 


\section{ACKNOWLEDGMENTS}

Research for this project was sponsored by the Office of Environmental Restoration, U. S. Department of Energy, under contract DE-AC05-84OR21400 with Lockheed Martin Energy Systems, Inc. The authors wish to acknowledge the contributions of V. P. Patania, D. A. Roberts, D. A. Rose, and J. M. Lovegrove of the Measurement Applications and Development Group for participation in the sample preparation and analyses, editing, graphics, and reporting of data for this survey. The surveying assistance of the staff on the survey team is also gratefully acknowledged. 


\begin{abstract}
The U. S. Department of Energy (DOE) conducted remedial action during 1993 at several vicinity properties in the Wayne and Pequannock Townships in New Jersey as part of the Formerly Utilized Sites Remedial Action Program (FUSRAP). These properties are in the vicinity of the DOE-owned Wayne Interim Storage Site (WISS), formerly the W. R. Grace facility. The property at 914 Black Oak Ridge Road, Wayne, New Jersey was not one of these vicinity properties; however the owner requested that his property be radiologically surveyed.
\end{abstract}

At the request of DOE, a team from Oak Ridge National Laboratory conducted a radiological scoping survey of this property. The purpose of the survey, conducted in early November 1993, was to determine whether any radiological contamination might be present on the property. The radiological survey included surface gamma scans and gamma readings at one meter, and the collection of soil and/or debris samples for radionuclide analysis.

Results of the survey demonstrated no radionuclide concentrations or radiation measurements in excess of applicable DOE guidelines. 


\section{RADIOLOGICAL SURVEY RESULTS AT 914 BLACK OAK RIDGE ROAD, WAYNE, NEW JERSEY (WJ005) ${ }^{*}$}

\section{INTRODUCTION}

As part of the Formerly Utilized Sites Remedial Action Program (FUSRAP), the Department of Energy (DOE) conducted a remedial action project in 1993 at several residential vicinity properties in the Townships of Pequannock and Wayne, New Jersey. Figure 1 shows the general location of these vicinity properties.

Although the property at 914 Black Oak Ridge Rd. was not one of the properties being surveyed, the owner had requested a survey of his property because radiological contamination had been found and was being remediated on the adjoining neighbor's property.

During early November, 1993, a team from the Oak Ridge National Laboratory (ORNL) conducted investigative radiological surveys of several properties in the Wayne and Pequannock, New Jersey area, and at the request of DOE, the team conducted a radiological scoping survey of this property. The survey consisted primarily of a complete gamma scan of the grounds and the collection of soil and gravel samples for radionuclide analysis.

This report describes the results of the radiological survey of the private residential property at 914 Black Oak Ridge Rd., Wayne, New Jersey, conducted by ORNL at the request of the Department of Energy's Office of Environmental Restoration.

The property at 914 Black Oak Ridge Rd., is a single family dwelling with separate three-car garage and a gravel drive that surrounds the house (Fig. 2).

A walkover survey of the property (a technician walks slowly over the property swinging a detection probe at $1-2$ inches from the ground surface) was conducted on November 2, 1993 by ORNL's Measurement Applications and Development Group. The purpose of the survey, which extended further to the east than the property boundary, was to determine the nature and extent of any radiological contamination that might be present on the property.

A field survey drawing showing $10-\mathrm{m}$ grids and indicating soil sampling locations and gamma radiation measurements is included in this report as Fig. 2.

\section{SCOPE OF THE SURVEY}

A comprehensive description of the survey methods and instrumentation used in this survey is given in Procedures Manual for the ORNL Radiological Survey Activities (RASA) Program, ORNL/TM-8600 (April 1987), and Measurement Applications and Development Group Guidelines, ORNL-6782 (January 1995).

\footnotetext{
* The survey was performed by members of the Measurement Applications and Development Group of the Health Sciences Research Division at Oak Ridge National Laboratory under DOE contract DE-AC05-84OR21400.
} 
The radiological survey of this property included: (1) a surface gamma scan of the grounds, sidewalks, and driveway, and (2) the collection of surface and subsurface soil samples for analysis.

Gamma radiation levels were determined using a portable sodium iodide (NaI) gamma scintillation detector connected to a Victoreen ratemeter. Measurements were recorded and converted to $\mu \mathrm{R} / \mathrm{h}$. Because $\mathrm{NaI}$ gamma scintillators are energy dependent, measurements of gamma radiation levels in counts per minute (CPM) are normalized to pressurized ionization chamber (PIC) measurements to estimate gamma exposure rates in $\mu \mathrm{R} / \mathrm{h}$.

Surface $(0-15 \mathrm{~cm}$, or 0 to 6 in) and subsurface $(15-45 \mathrm{~cm}$, or 6 to $18 \mathrm{in})$ soil samples, were collected randomly over the property. Confirmatory samples were taken from one location on the driveway on the south side of the house where elevated gamma levels had been identified. These are referred to as biased samples and are labeled as B1A and B1B. Systematic samples (S1-S9) were taken at locations irrespective of gamma exposure rates. Locations of the samples are shown in Fig. 2, and results of the analysis are shown in Table 1.

Direct measurement results presented in this report are gross readings; background radiation levels have not been subtracted. Similarly, background radiation levels have not been subtracted from radionuclide concentrations measured in environmental samples.

\section{SURVEY RESULTS}

Gamma measurements at one meter from the surface ranged from 9 to $15 \mu \mathrm{R} / \mathrm{h}$. Surface gamma measurements generally ranged from 10 to $12 \mu \mathrm{R} / \mathrm{h}$ in the grassy areas of the front and back yards, and up to $21 \mu \mathrm{R} / \mathrm{h}$ at the surface of the gravel drive. All of these measurements are comparable to background levels in the northern New Jersey area.

Surface and subsurface soil samples were collected from the front and back yards of the property, including two biased samples taken from the gravel driveway. All samples were analyzed for radium $\left({ }^{226} \mathrm{Ra}\right)$, thorium $\left({ }^{232} \mathrm{Th}\right)$, and uranium $\left({ }^{238} \mathrm{U}\right)$.

Results of the soil analyses are in picocuries per gram $(\mathrm{pCi} / \mathrm{g})$ and are shown in Table 1. A curie ( $\mathrm{Ci}$ ) is a unit used to express activity of radionuclides. Radionuclide concentrations of $226 \mathrm{Ra}$ and $232 \mathrm{Th}$ ranged from 0.62 to $1.2 \mathrm{pCi} / \mathrm{g}$ in the systematic samples, which are comparable to typical average background levels for the northern New Jersey area of $0.9 \mathrm{pCi} / \mathrm{g}$ for these radionuclides (T. E. Myrick, et al., ORNL/TM7343,1981 ), and well below the DOE guideline for these radionuclides in soil, which is 5 and $15 \mathrm{pCi} / \mathrm{g}$ above background averaged over $100 \mathrm{~m}^{2}$ for surface and subsurface soil, respectively. ${ }^{*}$ Ranges for the biased samples, taken from the graveled area were from 0.71 to $1.7 \mathrm{pCi} / \mathrm{g}$ for ${ }^{226} \mathrm{Ra}$, and 0.96 to $2.4 \mathrm{pCi} / \mathrm{g}$ for ${ }^{232} \mathrm{Th}$, which are also well below DOE guidelines.

\footnotetext{
${ }^{*}$ For residential properties in this area the guideline for ${ }^{232} \mathrm{Th}$ is $5 \mathrm{pCi} / \mathrm{g}$ for both surface and subsurface soil.
} 
Concentrations of $238 \mathrm{U}$ in soil ranged from 0.78 to $1.3 \mathrm{pCi} / \mathrm{g}$ in biased samples (gravel), and from $\sim 3.2$ to $6.6 \mathrm{pCi} / \mathrm{g}$ in systematic samples (see Table 1). All these values are also below the site specific guidelines for uranium in soil. ${ }^{* *}$

\section{SIGNIFICANCE OF FINDINGS}

Generally, gamma measurements on the property at 914 Black Oak Ridge Road, Wayne, New Jersey were comparable to the average values for the area and were well below DOE guidelines. The slightly elevated gamma measurements found on the driveway are attributable to the naturally occurring radiological elements in the gravel (predominantly $40 \mathrm{~K}$, which ranged from 12 to $20 \mathrm{pCi} / \mathrm{g}$ ), as indicated by the radionuclide analysis of samples from the drive. Furthermore, the results of the soil analysis showed that the lawn soil contained normal levels of radionuclides for the New Jersey area. Based on the results of this survey, it is believed that no radiological contamination is present on the property.

${ }^{* *}$ DOE guidelines for uranium are derived on a site-specific basis. Guidelines of $100 \mathrm{pCi} / \mathrm{g}$ have been applied to this FUSRAP site. Source: Memo, J. W. Wagoner II, Director, Division of Off-Site Programs, Office of Environmental Restoration, U. S. Department of Energy, to L. K. Price, Director, Former Sites Restoration Division, Oak Ridge Field Office, U. S. DOE, April 25, 1995. 


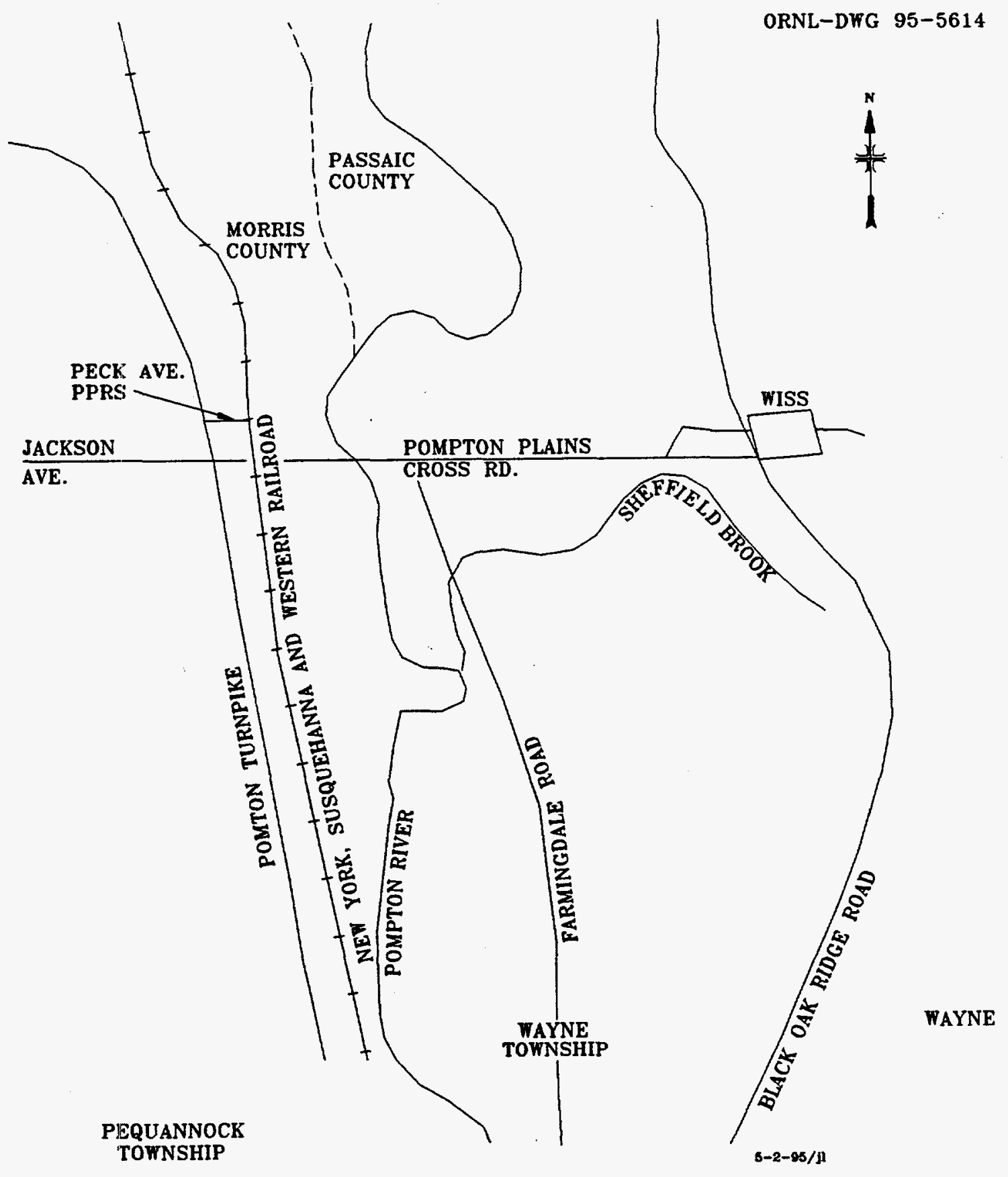

Fig. 1. Diagram showing general location of the Wayne Interim Storage Site (WISS) relative to the Wayne and Pequannock, New Jersey vicinity properties. 


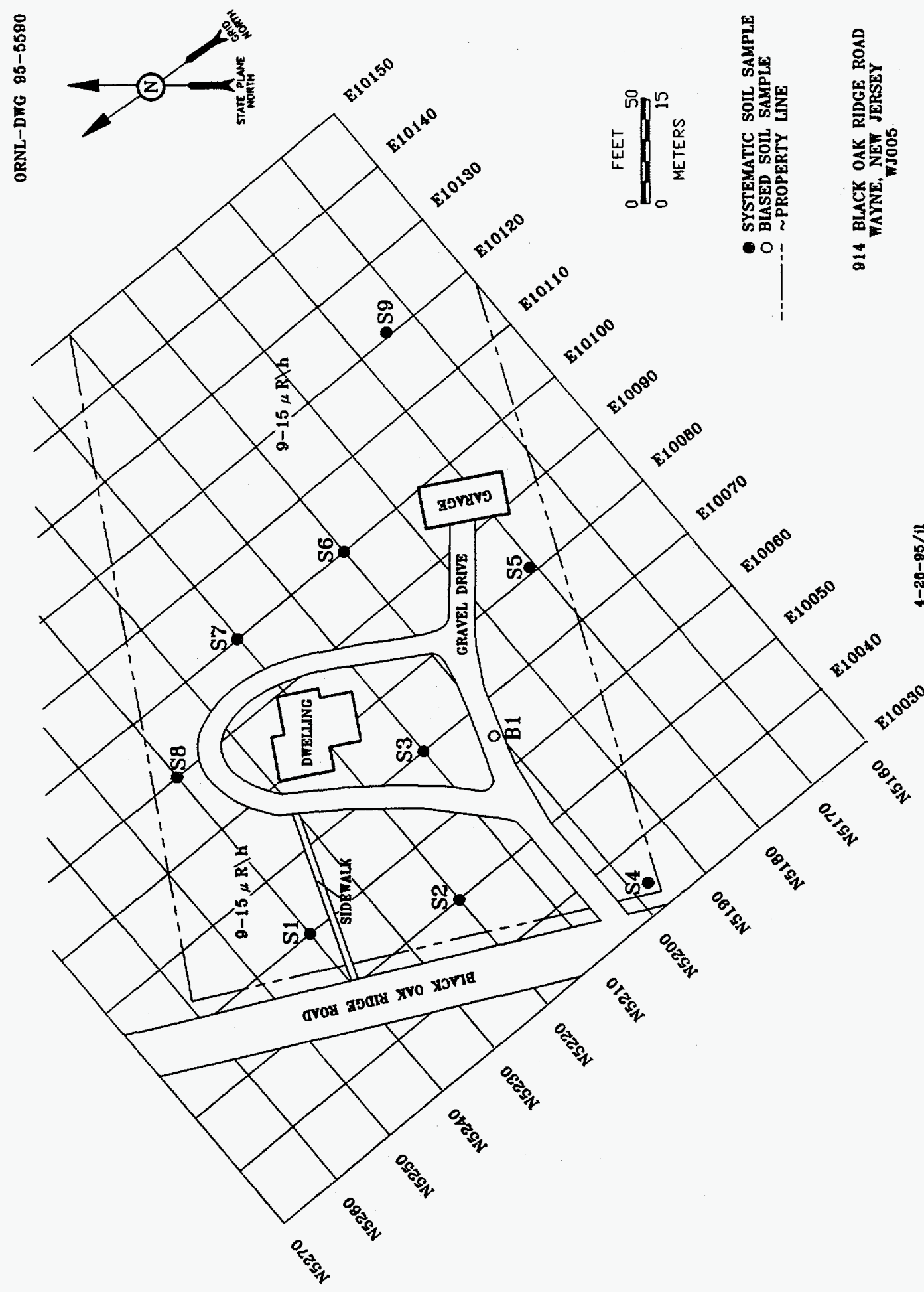

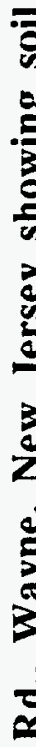

స

ฮै

블

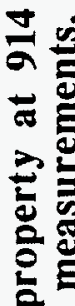

톨

통

究

อิ

ํํㅇ

톨 
Table 1. Concentrations of radionuclides in soil and other materials at 914 Black Oak Ridge Rd., Wayne, New Jersey (WJ005)

\begin{tabular}{|c|c|c|c|c|c|}
\hline \multirow{2}{*}{$\begin{array}{l}\text { Sample } \\
\text { numbera }\end{array}$} & \multirow{2}{*}{$\begin{array}{c}\text { Grid } \\
\text { location }\end{array}$} & \multirow{2}{*}{$\begin{array}{c}\text { Depth } \\
\text { (cm) }\end{array}$} & \multicolumn{3}{|c|}{ Radionuclide concentration $(\mathrm{pCi} / \mathrm{g}$} \\
\hline & & & $226 \mathrm{Ra}$ & ${ }^{232} \mathrm{Th}$ & $238 \mathrm{U}$ \\
\hline & & \multicolumn{4}{|c|}{ Systematic soil samplesc } \\
\hline$S 1$ & $5240 \mathrm{~N}, 10060 \mathrm{E}$ & $0-15$ & $0.68 \pm 0.06$ & $1.00 \pm 0.1$ & $<4.3$ \\
\hline$\$ 2$ & $5220 \mathrm{~N}, 10050 \mathrm{E}$ & $0-15$ & $0.66 \pm 0.08$ & $0.90 \pm 0.2$ & $<6.0$ \\
\hline S3 & $5210 \mathrm{~N}, 10070 \mathrm{E}$ & $0-15$ & $0.77 \pm 0.07$ & $1.2 \pm 0.2$ & $<4.4$ \\
\hline S4 & $5198 \mathrm{~N}, 10033 \mathrm{E}$ & $0-15$ & $0.62 \pm 0.09$ & $0.98 \pm 0.2$ & $<6.6$ \\
\hline S5 & $5180 \mathrm{~N}, 10080 \mathrm{E}$ & $0-15$ & $0.88 \pm 0.05$ & $1.1 \pm 0.1$ & $<3.2$ \\
\hline S6 & $5200 \mathrm{~N}, 10100 \mathrm{E}$ & $0-15$ & $0.73 \pm 0.09$ & $1.05 \pm 0.2$ & $<5.3$ \\
\hline S7 & $5220 \mathrm{~N}, 10100 \mathrm{E}$ & $0-15$ & $0.75 \pm 0.07$ & $1.01 \pm 0.1$ & $<4.7$ \\
\hline S8 & $5240 \mathrm{~N}, 10090 \mathrm{E}$ & $0-15$ & $0.81 \pm 0.07$ & $1.2 \pm 0.1$ & $<4.9$ \\
\hline S9A & $5175 \mathrm{~N}, 10120 \mathrm{E}$ & $0-15$ & $0.78 \pm 0.07$ & $0.89 \pm 0.1$ & $<4.4$ \\
\hline S9B & & $15-30$ & $0.74 \pm 0.08$ & $0.99 \pm 0.2$ & $<5.9$ \\
\hline
\end{tabular}

\section{Biased samplesd}

$\begin{array}{lccccl}\text { B1A } & 5200 \mathrm{~N}, 10063 \mathrm{E} & 0-15 & 1.7 \pm 0.1 & 2.4 \pm 0.2 & 1.3 \pm 0.50 \\ \text { B1B } & & 15-30 & 0.71 \pm 0.1 & 0.96 \pm 0.1 & 0.78 \pm 0.4\end{array}$

aLocations of soil samples are shown on Fig. 2.

bIndicated counting error is at the $95 \%$ confidence level $( \pm 2 \sigma)$.

c Systematic samples are taken at locations irrespective of gamma exposure rates.

${ }^{d}$ Biased samples are taken from areas with elevated gamma exposure rates. 
ORNL/RASA-95/9

\section{INTERNAL DISTRIBUTION}

\author{
1. B. A. Berven \\ 2. K. J. Brown \\ 3. R. F. Carrier \\ 4. R. D. Foley \\ 5-7. C. A. Johnson \\ 8. M. E. Murray \\ 9. P. T. Owen \\ 10-12. R. E. Rodriguez
}

13. R. E. Swaja

14. M. S. Uziel

15. J. K. Williams

16. Central Research Library

17-18. Laboratory Records

19. Laboratory Records-RC

20. ORNL Patent Section

21. ORNL Technical Library, $\mathrm{Y}-12$

22-27. MAD Records Center

\section{EXTERNAL DISTRIBUTION}

28. W. L. Beck, Oak Ridge Associated Universities, E/SH Division, Environmental Survey and Site Assessment Program, P.O. Box 117, Oak Ridge, TN 37831-0117

29. Jack Russell, Booz-Allen \& Hamilton, Inc., Trevion I Bldg., Suite 210, 12850 Middlebrook Rd., Bethesda, MD 20814

30. James J. Fiore, Director, Office of Eastern Area Programs, Office of Environmental Restoration, EM-24, U.S. Department of Energy, 19901 Germantown Rd., Germantown, MD 20874-1290

31-33. R. R. Harbert, Bechtel National, Inc., FUSRAP Department, Oak Ridge Corporate Center, 151 Lafayette Drive, P.O. Box 350, Oak Ridge, TN 37831-0350

34-36. J. King, Science Applications International Corporation, P.O. Box 2501, 301 Laboratory Road, Oak Ridge, TN 37831

37. L. K. Price, Director, Former Sites Restoration Division, Oak Ridge Field Office, U.S. Department of Energy, P.O. Box 2001, Oak Ridge, TN 37831-8723

38. James W. Wagoner II, Director, Division of Off-Site Programs, Office of Eastern Area Programs, Office of Environmental Restoration, EM-421, U.S. Department of Energy, 19901 Germantown Rd., Germantown, MD 20874-1290

39-43. W. Alexander Williams, Designation and Certification Manager, Division of OffSite Programs, Office of Eastern Area Programs, Office of Environmental Restoration, EM-421, U.S. Department of Energy, 19901 Germantown Rd., Germantown, MD 20874-1290

44-45. Office of Scientific and Technical Information, U.S. Department of Energy, P.O. Box 62, Oak Ridge, TN 37831

46. Office of Assistant Manager, Energy Research and Development, U.S. Department of Energy, DOE Field Office, P.O.Box 2008, Oak Ridge, TN 37831-6269 